\title{
BENARKAH ALQURAN HANYA SATU?
}

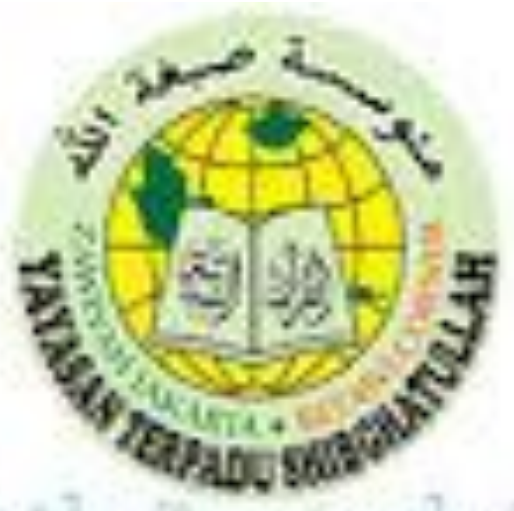

Disusun oleh:

Setiyo Mahfudz Ashari

Mahasantri S2 


\title{
BENARKAH ALQURAN ITU HANYA SATU?
}

\author{
Oleh Setiyo Mahfudz Ashari
}

\begin{abstract}
Abstrak
Euforia menyongsong kebangkitan Islam masih memiliki permasalahan, terlebih jika menyangkut pengetahuan tentang Alquran yang merupakan sumber pokok dalam Islam. Oleh karena itu mengenali Alquran secara benar merupakan hal mendasar yang mendesak untuk segera disikapi. Penelitian ini bersifat library research. Metode yang digunakan adalah content analysis. Metode content analysis dipergunakan untuk menggali pemahaman dan pemikiran serta pendapat para ulama Alquran yang terdapat dalam kitab-kitab mereka. Diantaranya Al Imam Jalaluddin Abdurrahman bin Abi Bakr Assuyuthi (wafat $911 \mathrm{H}$ ) dengan judul kitabnya "Al Itqon fi 'Ulumil Qur'an", Manna' Khalil Al Qatthan (1925-1999 M) dengan kitabnya "Mabahits fi 'Ulumil Qur'an", 'Ali Ismail Assayyid Hindawi (wafat $1410 \mathrm{H}$ ) dengan kitabnya "Jaami'ul Bayaan fi Ma'rifati Rasmil Qur'an", Dr. KH. Ahmd Fathoni, MA dengan kitab-kitabnya, "Kaidah Qiraat Tujuh", "Ilmu Rasm Usmani", "Metode Maisura" dan "Tuntunan Praktis Qira'at Nafi' Riwayat Warsy", serta Dr. KH. Muhsin Salim, MA dengan kitabnya "Ilmu Al Qur'an Rasam Utsmani". Sehingga keragaman Alquran yang dimiliki umat Islam merupakan sebuah rahmat dari Allah Ta'ala untuk menjadi panduan dalam menjalin kehidupan dimuka bumi ini sebagai hamba Allah dan sebagai khalifah fil ardh dan sebagai khazanah keilmuan yang patut kita pelajari dan dakwahkan agar seluruh kaum muslimin terbuka pandangannya dan wawasannya sehingga dapat mempererat ukhuwah sera benturan-benturan dalam menjaga ukhuwah islamiyah dapat dikurangi.
\end{abstract}

Kata Kunci: Keragaman Alquran

\section{A. Pendahuluan}

Semangat menyongsong kebangkitan Islam yang dilakukan umat beberapa tahun terakhir ini begitu terasa. Ditandai dengan maraknya kemunculan produk-produk yang berlabelkan syari'ah; banyaknya karyawati customer service atau petugas front office yang mengenakan hijab meski kantor atau lembaga tempat bekerjanya merupakan lembaga publik, baik dibawah kepemerintahan ataupun swasta; menjamurnya lembaga-lembaga pendidikan Islam yang menyelenggarakan program tahfidzul Quran; serta meningkatnya sensitifitas perhatian masyarakat Muslim terhadap segala hal yang terkait keIslaman. 
Pada pertengahan Mei tahun 2015 pernah terjadi keriuhan masyarakat ketika ada seorang pembaca Alquran dalam sebuah acara seremonial di Istana Negara membaca Alquran dengan langgam jawa hingga hampir seluruh media cetak terlebih elektronik turut mengangkatnya sebagai berita dalam beberapa disertai dengan tanggapan dari berbagai pihak. ${ }^{1}$

Dan pada pertengahan Oktober 2018 tersebarnya sebuah video dari daerah Madura yang berisi informasi temuan sebuah Alqur'an palsu dengan menyebutkan dalam video tersebut perekam video menyebutkan, "Tolong kalau ada terutama didaerah Indun kawasan Madura, yang dikawasan Indun-lah terutama, tolong, tolong, Qur'an semacam ini jangan dipake, tolong liat bingkainya, bentuknya, kalau ada yang sama, tolong dibuang saja, atau diamankan..."2 Sebulan sebelumnya pada tahun tersebut terlaksana Mukernas Ulama Alquran Indonesia oleh Lajnah Pentashihan Mushaf Alquran (LPMQ) untuk Penyempurnaan Tulisan Alquran yang menghasilkan sebanyak 186 kata akan dilakukan perubahan penulisannya ${ }^{3}$. Informasi tersebut sempat menimbulkan prasangka akan diubahnya mushaf Alquran yang beredar di Indonesia menjadi Alquran Nusantara setelah sebelumnya ada polemik terkait perdebatan pandangan adanya Islam Nusantara.

Dengan demikian, euforia menyongsong kebangkitan Islam masih memiliki permasalahan, terlebih jika menyangkut pengetahuan tentang Alquran yang merupakan sumber pokok dalam Islam. Oleh karena itu mengenali Alquran secara benar merupakan hal mendasar yang mendesak untuk segera disikapi. Penelitian ini fokus untuk menjawab satu pertanyaan besar, benarkah Alquran yang dimiliki umat Islam hanya satu?

\section{B. Metode Penelitian}

Penelitian ini bersifat library research. Metode yang digunakan adalah content analysis. Metode content analysis dipergunakan untuk menggali pemahaman dan pemikiran serta pendapat para ulama Alquran yang terdapat dalam kitab-kitab mereka. Diantaranya Al Imam Jalaluddin Abdurrahman bin Abi Bakr Assuyuthi (wafat $911 \mathrm{H}$ ) dengan judul kitabnya "Al Itqon fi 'Ulumil Qur'an", Manna' Khalil Al Qatthan (1925-1999 M) dengan kitabnya "Mabahits fi 'Ulumil Qur'an”, 'Ali Ismail Assayyid Hindawi (wafat 1410 H) dengan kitabnya

\footnotetext{
${ }^{1}$ https://www.republika.co.id/berita/dunia-islam/islam-nusantara/15/05/17/nohjmt-wasekjen-mui-bacaalquran-di-istana-pakai-langgam-jawa-adalah-memalukan , 17 September 2020, 21:24

2 https://www.youtube.com/watch?v=-RuzILScrM8\&t=27s 13 September 2020, 14:50.

3 https://republika.co.id/berita/dunia-islam/islam-nusantara/18/09/28/pfrk90384-penyempurnaan-tulisanalquran-mengikuti-mushaf-utsmani 13 September 2020, 14:54
} 
"Jaami'ul Bayaan fi Ma'rifati Rasmil Qur'an", Dr. KH. Ahmd Fathoni, MA dengan kitab-kitabnya, "Kaidah Qiraat Tujuh", "Ilmu Rasm Usmani", "Metode Maisura" dan "Tuntunan Praktis Qira'at Nafi' Riwayat Warsy", serta Dr. KH. Muhsin Salim, MA dengan kitabnya "Ilmu Al Qur'an Rasam Utsmani". Dari penelitian tersebut, penulis berusaha memunculkan realita yang sesungguhnya terkait Alquran sehingga meluruskan pandangan yang sebenarnya terhadap keaslian, kemurnian dan keberagamannya Alquran.

\section{Pembahasan}

\section{Pengertian Alquran}

Alquran berasal dari kata قَ قَرَ yang menurut bahasa artinya adalah berkumpulnya huruf dan kalimat, satu bagian kepada bagian yang lain dalam

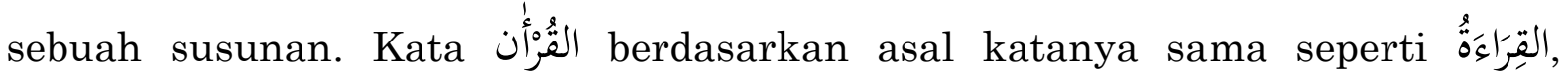

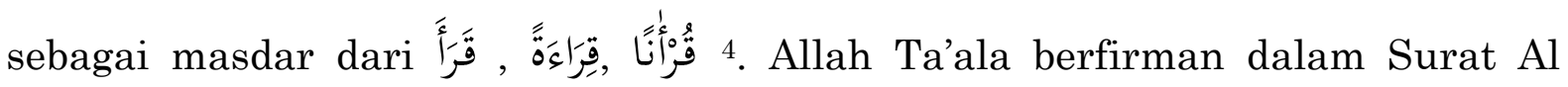
Qiyamah ayat 17-18:

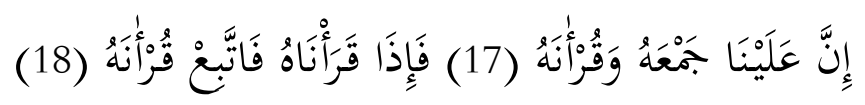

"Sesungguhnya atas tanggungan Kamilah mengumpulkannya (di dadamu) dan (membuatmu pandai) membacanya. Apabila Kami telah selesai membacakannya, maka ikutilah bacaannya itu."

Para ulama membuat definisi yang mebedakan antara Alquran dengan bacaan-bacaan lainnya dengan istilah:

$$
\text { كلام الله، المنزل على محمد -صلى الله عليه وسلم- المتعبد بتلاوته }
$$

"Firman Allah yang diturunkan kepada Nabi Muhammad aلlugate yang terhitung sebagai ibadah dalam membacanya."6

\footnotetext{
${ }^{4}$ Al Qaththan, Manna Khalil. (tt). Mabahits fii 'Ulumil Qur'an. Riyadh: Ma'had Aly Lil Qadha. Hal. 20

${ }^{5}$ Al Qur'an dan Terjemahnya, Departemen Agama RI, hal. 999

${ }^{6}$ Al Qaththan, op.cit.. Hal. 21
} 
Alquran diturunkan dengan beragam bacaan

Alquran merupakan Kalamullah (firman Allah) yang diturunkan Allah Azza Wa Jalla melalui malaikat Jibril a.s kepada nabi Muhammad wلw melalui perpindahan suara yakni malaikat Jibril a.s membacakannya kepada nabi Muhammad allugale kemudian beliau mengikuti bacaannya. Dan nabi Muhammad

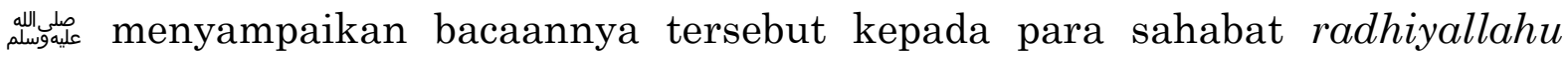
Ta'ala 'anhum sebagai bentuk penyampaian risalah yang Allah utus beliau untuk hal tersebut. Pada saat penyampaian bacaan ayat-ayat Alquran kepada para sahabat kondisinya bermacam-macam. Adakalanya banyak sahabat yang sedang berkumpul, adakalanya sedikit dan terkadang juga hanya ada 1 atau 2

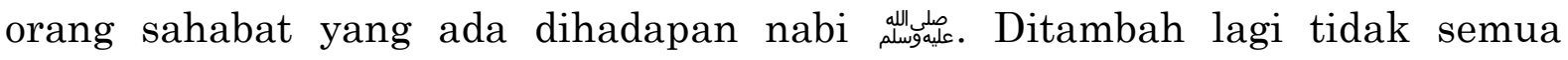
sahabat nabi dapat menulis ayat-ayat Alquran yang dibacakan, meskipun tulisan Alquran oleh beberapa sahabat secara utuh akhirnya terkumpul pada masa sayyidina 'Utsman r.a. Keadaan-keadaan seperti tersebut diatas, sangat memungkinkan terjadinya selisih paham mengenai cara membaca Alquran mengingat secara jelas bahwa Rasulullah allusale meminta malaikat Jibril a.s untuk mengajarkan kepadanya lebih dari satu wajah/bentuk bacaan dengan sabda beliau aلd a divale :

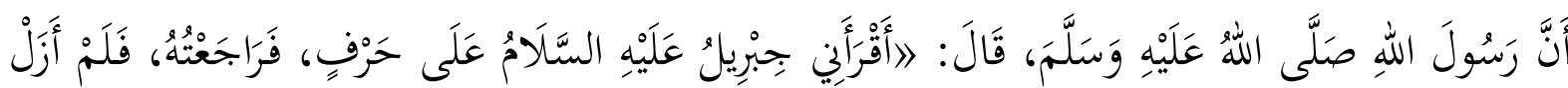

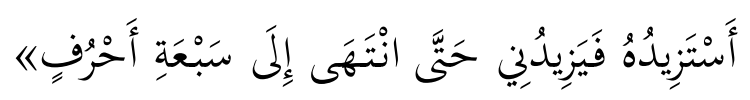

Rasulullah aلswede bersabda, "Jibril telah membacakan Alquran kepadaku dalam satu huruf. Aku berulang-ulang membacanya. Selanjutnya aku selalu meminta kepadanya agar ditambah, sehingga ia menambahnya sampai tujuh huruf". (Hr. Al-Bukhari, Muslim)

Selisih paham mengenai cara membaca Alquran ini termaktub dengan jelas dalam sebuah hadits panjang berikut ini:

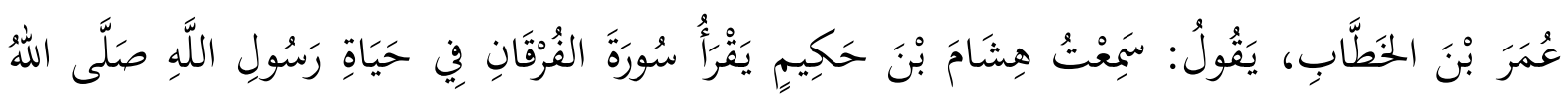

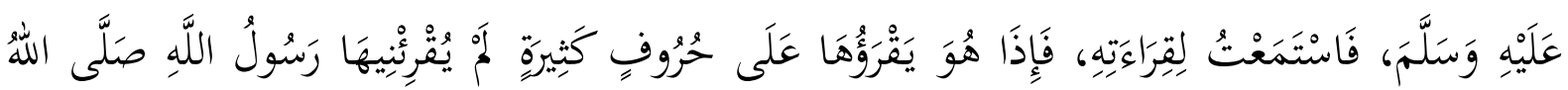

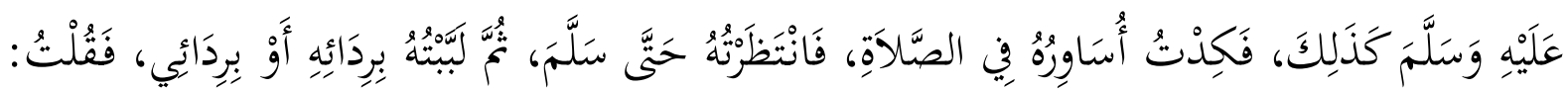

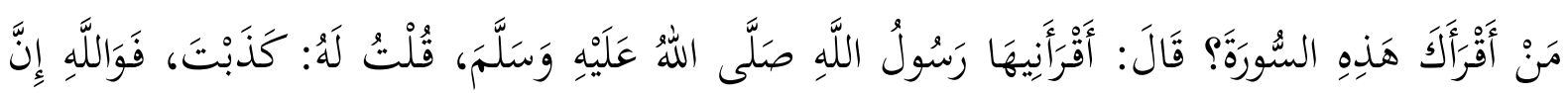

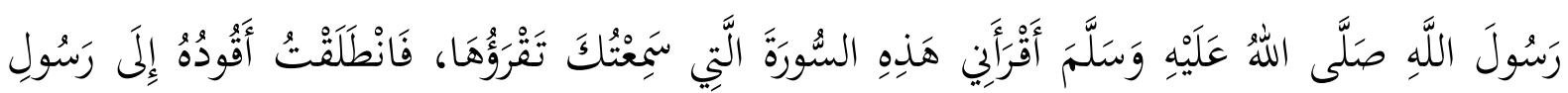




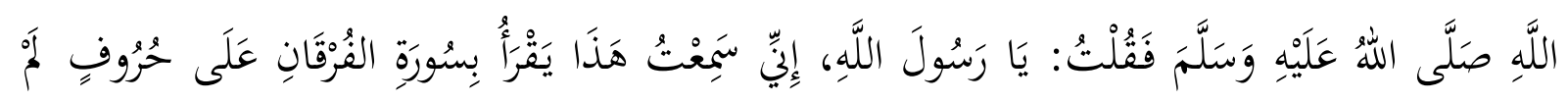

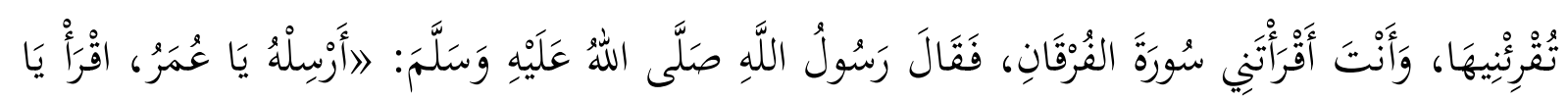

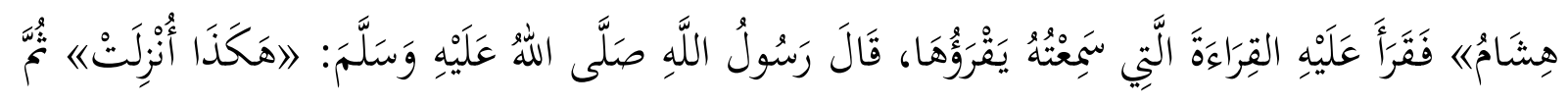

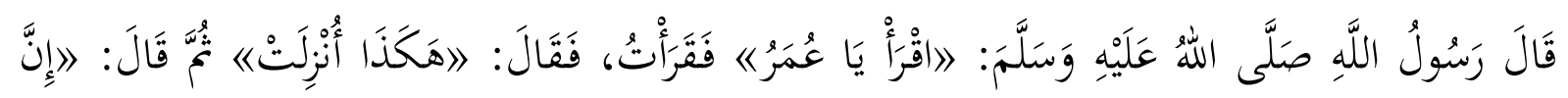

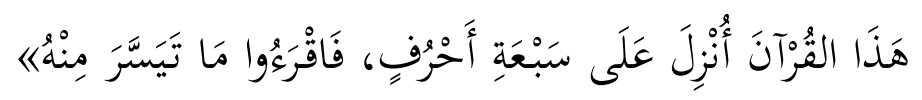

'Umar bin Khattab r.a berkata, "Aku mendengar Hisyam bin Hakim membaca surat Al Furqan di masa hidup Rasulullah aلdusale. Lalu aku sengaja mendengarkan bacaannya. Tiba-tiba dia membacanya dengan bacaan yang bermacam-macam yang belum pernah dibacakan Nabi kepadaku. Hampir saja aku serang dia dalam shalat, namun aku berusaha menunggu dengan sabar sampai dia salam. Begitu dia salam aku tarik leher bajunya, seraya aku bertanya, "Siapa yang mengajari bacaan surat ini?" Hisyam menjawab, "Yang mengajarkannya adalah Rasulullah sendiri". Aku gertak dia, "Kau bohong, demi Allah, Rasulullah telah membacakan kepadaku surat yang kau baca tadi (tetapi tidak seperti bacaanmu). Maka kuajak dia menghadap Rasulullah dan kukatakan, "Wahai Rasulullah, aku mendengar orang ini membaca surat $\mathrm{Al}$ Furqan dengan bermacam-macam bacaan yang belum pernah engkau bacakan kepadaku. Dan engkau telah membacakan kepadaku surat Al Furqan”. Lalu Rasulullah a bersabda: "Lepaskan (leher bajunya), wahai Umar. Bacalah, wahai Hisyam". Lalu ia membaca surat Al Furqan sebagaimana yang dibaca tadi. Kemudian Rasulullah aلdugate berkomentar, "Demikianlah bacaan surat itu diturunkan”. Kemudian Rasulullah aلd bersabda, "Bacalah, wahai Umar!", lalu aku membacanya, Kemudian Rasulullah aلd bersabda, "Demikianlah bacaan surat itu diturunkan". Kemudian Rasulullah bersabda lagi, "Sesungguhnya Alquran itu diturunkan dalam tujuh huruf, maka bacalah mana yang kalian anggap mudah". (Hr. Al Bukhari, Muslim, Abu Daud, An Nasai, At Tirmidzi, Ahmad dan Ibnu Jarir)

Selisih paham tentang cara membaca Alquran pada zaman Rasulullah

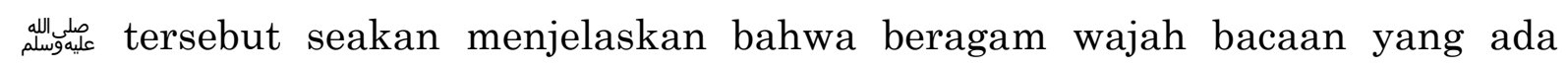
bukanlah karangan Nabi Muhammad allugate atau para sahabat atau Ulama tabi'in yang dipengaruhi oleh dialek bahasa kabilah-kabilah Arab. Dan jelas pula bahwa macam-macam bacaan itu sudah ada sejak Alquran diturunkan.

Pada masa Rasulullah aلd masih hidup saja, salah paham terkait bacaan Alquran sempat terjadi, bagaimana dengan masa kita saat ini yang telah 
melawati 1400 tahun dari masa Rasulullah aلdusate hidup? Ditambah lagi dengan penulisan mushaf yang ternyata juga memiliki beragam perbedaan mengikuti perbedaan wajah bacaan.

Berikut gambar dari 3 contoh mushaf dari beragamnya mushaf yang ada saat ini:

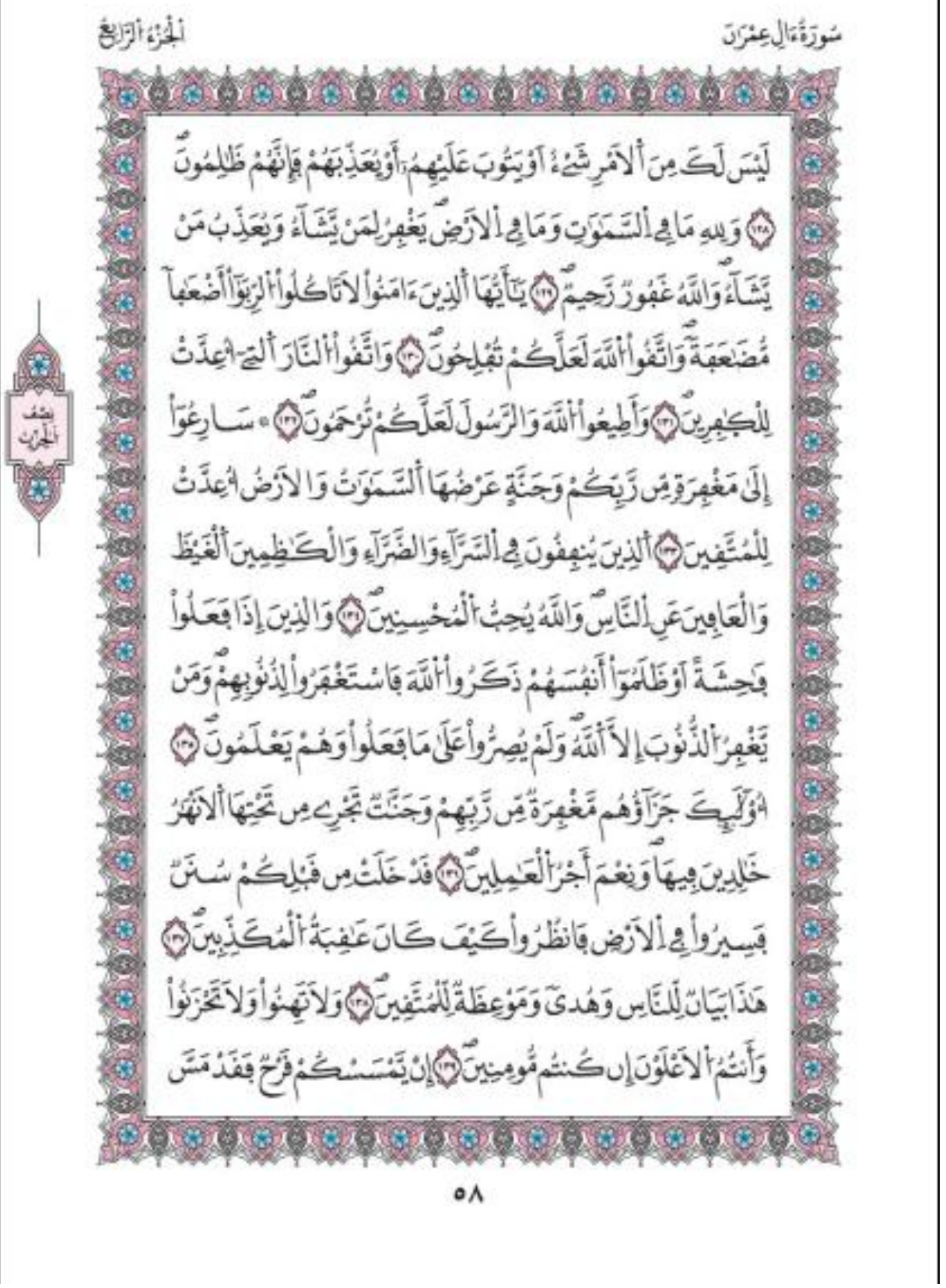

Mushaf Madinah Nabawiyah Riwayat Warsh 'An Nafi' 


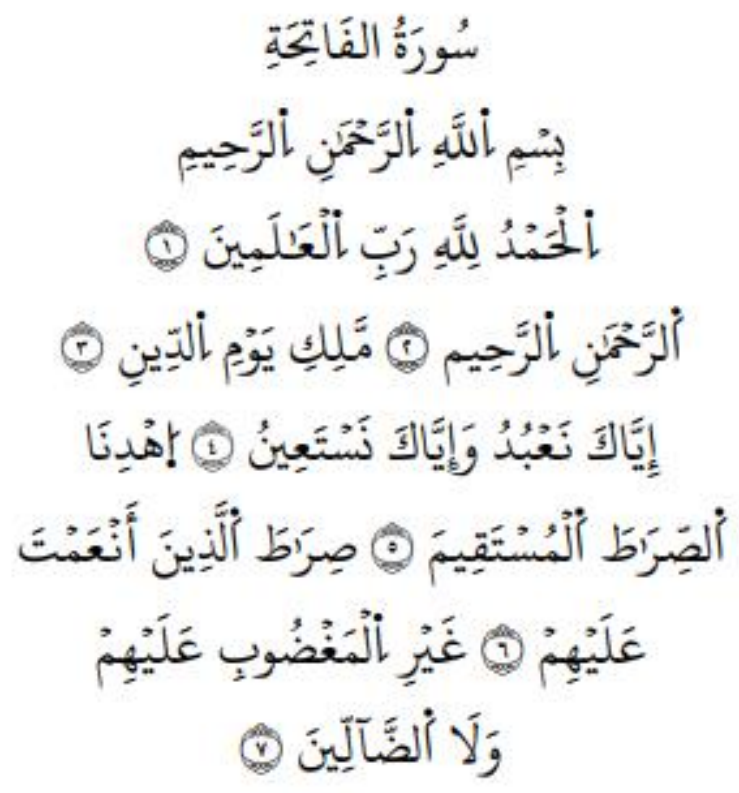

Majma' Al Malik Fahd Percetakan Mushaf Asy Syarif, Riwayat As Susi 'an Abi Amr

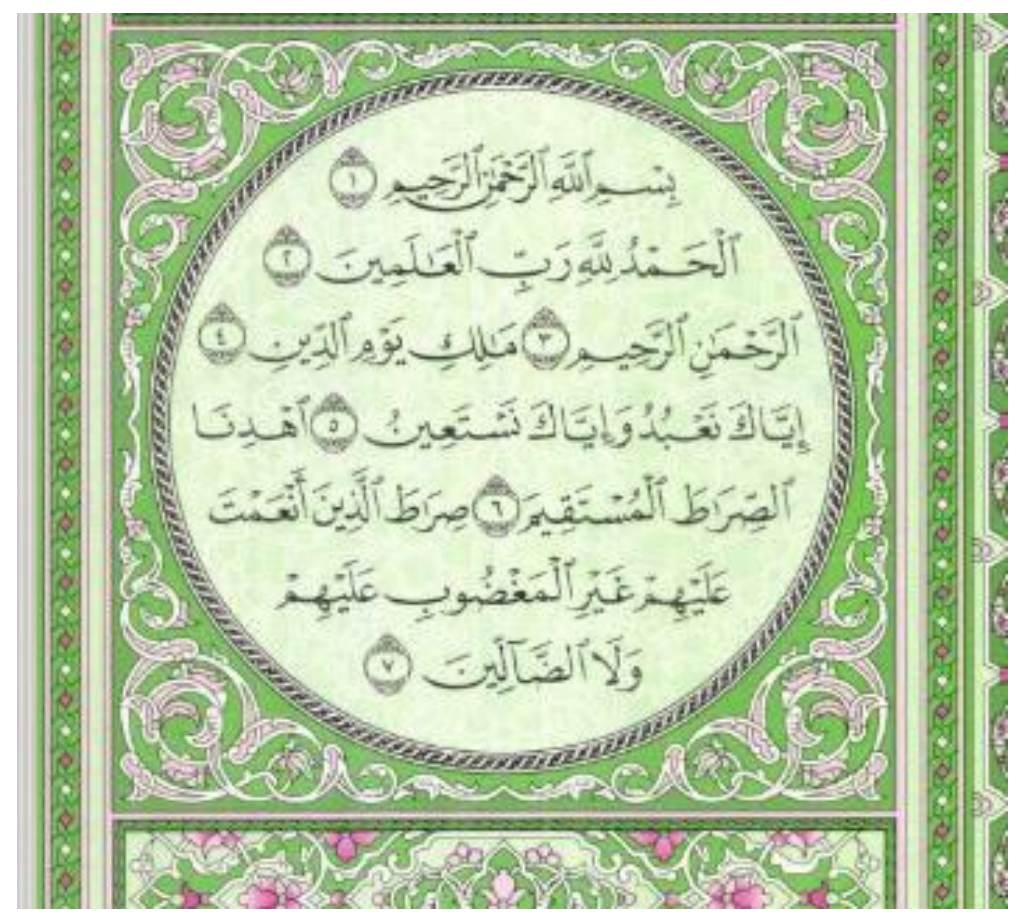

Mushaf Madinah Nabawiyah Riwayat Hafsh 'an 'Ashim 
Dengan memperhatikan beberapa mushaf tersebut, tampak jelas betapa beragamnya wajah bacaan dan penulisan Alquran. Al Qaadhi Jalaluddin Al Bulqini mengatakan bahwa Qiroat (bacaan Alquran) itu terbagi pada Mutawatir, Aahad dan Syaadz.

Qiroat Mutawatir adalah tujuh wajah / bentuk bacaan yang telah masyhur (terkenal).

Qiroat Aahad adalah tiga wajah / bentuk bacaan yang melengkapi tujuh bentuk bacaan sebelumnya sehingga genap sepuluh dan melekat dengannya bacaan sahabat.

Sedangkan Qiroat Syaadz adalah bacaan tabiin, seperti Al A'masy, Yahya bin Watstsaab, Ibnu Jubair dan lain-lain.

Pendapat yang terbaik dari Syaikh Abul Khair bin Al Jazari terkait persyaratan Qiroat yang diterima-sebagaimana terdapat pada awal kitab An Nasyr- adalah setiap qiroat yang sesuai dengan bahasa Arab meskipun dengan satu wajah / bentuk bacaan, dan sesuai dengan salah satu dari mashahif 'Utsmaniyyah meskipun dengan perkiraan kemungkinannya serta shahih sanadnya, maka itu adalah qiroat shohihah yang tidak boleh ditolak dan tidak boleh diingkari. Bahkan hal itu merupakan sab'atu ahruf (tujuh wajah bacaan) yang dengannya Alquran diturunkan serta wajib bagi seluruh manusia untuk menerimnya. Baik dari para imam yang tujuh atau sepuluh atau selain mereka dari para imam yang dapat diterima (dipercaya). Ketika salah satu dari tiga hal pokok tersebut hilang, maka qiroat tersebut adalah lemah secara mutlak atau tergolong syaadz (menyimpang dari ketentuan) atau bathil meskipun berasal dari imam yang tujuh atau yang lebih besar dari mereka. Pendapat inilah yang shahih menurut para imam yang mendalam ilmunya dari kalangan salaf maupun khalaf. Ad Dani, Makkiy, Al Mahdawiy dan Abu Syaamah menjelaskan hal tersebut dan itulah pendapat (madzhab) para ulama terdahulu yang tiada perbedaan diantara mereka. ${ }^{7}$

Ibnul Jazari menjelaskan maksud kesesuaian dengan bahasa Arab meskipun dengan satu wajah atau bentuk adalah kesesuaiannya dengan wajah atau bentuk kaidah nahwu. Baik yang afshah (paling fashih) ataupun yang fashih saja, yang disepakati atau yang terdapat perbedaan yang tidak merusak, apabila macam-macam bacaan yang menyebar tersebut diterima oleh para imam dengan sanad yang shohih, itulah dia bacaan yang pokok dan kuat.

Berikutnya Ibnul Jazari menjelaskan bahwa kesesuaian dengan salah satu dari mashahif 'utsmaniyah adalah tertulisnya secara jelas dan tetap pada

\footnotetext{
${ }^{7}$ As Suyuthi, Jalaluddin Abdurrahman bin Abi Bakr, 2019, Al Itqon Fi 'Ulumil Quran, Beirut: Dar Al Kotob Al Ilmiyah, hal. 116
} 
salah satu dari mushaf 'utsmaniyah meskipun tidak tertulis pada mushafmushaf yang lain. Seperti qiroat Ibnu Amir pada surat Al Baqoroh ayat 116

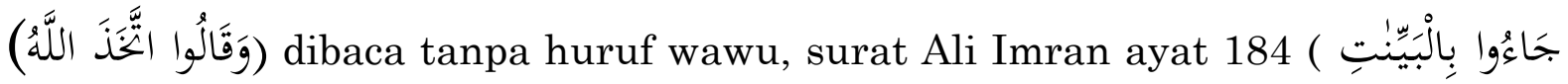

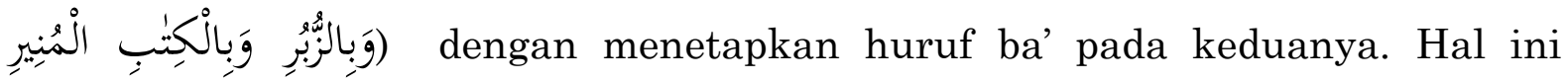
tertulis dengan jelas pada Mushaf Syamiy. Dan seperti qiroat Ibnu Katsir pada

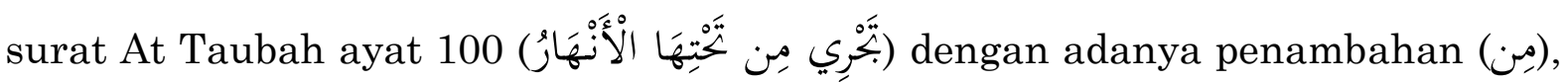
dan hal ini tertulis pada Mushaf Makky. Dan lain sebagainya. Apabila ada bacaan yang tidak terdapat pada salah satu mushaf dari mashahif "utsmaniyyah maka bacaan itu menyimpang dari ketentuannya (syaadz), karena bertentangan dengan Rasm yang telah disepakati secara ijma'.

Lebih lanjut Ibnul Jazari menjelaskan maksud dari meskipun dengan perkiraan kemungkinannya adalah sesuatu yang sesuai meskipun dengan perkiraan, seperti lafadz (مُلِكِ يَوْمُ الدَّينِ). Lafadz tersebut tertulis tanpa adanya huruf alif (l) pada semua mushaf 'utsmaniyyah. Maka adapun bacaan yang membaca pendek (مَلِكِ) / membuang huruf alif itu sesuai secara hakikat tulisannya, dan adapun bacaan yang membaca panjang (ملِكِ) / menetapkan alif itu sesuai secara taqdiiran (perkiraan), karena membuang tulisan huruf alif adalah untuk meringkas sebagaimana tertulis pada surat Ali Imran ayat 26 8. مُلِكَ الْمُلْكِ).

\section{Rasm Utsmani}

Rasm 'Utsmani adalah cara penulisan kalimah atau lafadz Alquran yang telah disetujui oleh sahabat Utsman bin Affan pada waktu penulisan mashahif utsmaniyah yang berjumlah enam buah yang ejaannya merujuk pada suhuf Abu Bakar dan diketahui bahwa suhuf Abu Bakar adalah hasil pengumpulan atau

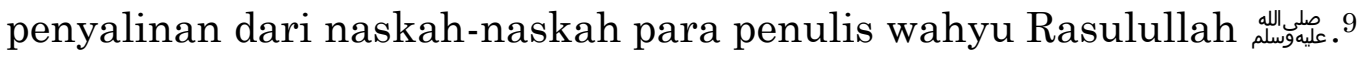

Mashahif utsmaniyyah adalah mushaf-mushaf yang ditulis oleh tim penulis ulang Mushaf yang dipimpin oleh Zaid bin Tsabit pada masa Khalifah Utsman bin Affan. Menurut pendapat yang masyhur terdapat 6 (enam) mushaf:

1. Mushaf Basrah (mushaf yang dikirim ke kota Basrah)

\footnotetext{
${ }^{8}$ Ibid., hal. 116

${ }^{9}$ Fathoni, Ahmad, 2016, Petunjuk Praktis Tahsin Tartil Metode Maisura, Jakarta: Yayasan Bengkel Metode Maisura, hal. 351
} 
2. Mushaf Kufah (mushaf yang dikirim ke kota Kufah)

3. Mushaf Syam (mushaf yang dikirim ke kota Syam)

4. Mushaf Makkah (mushaf yang dikirim ke kota Makka)

5. Mushaf Madani Al 'Am (mushaf penduduk Madinah)

6. Mushaf Madani Al Khash (mushaf yang disimpan Utsman bin Affan untuk diri sendiri). Biasa juga mushaf ini disebut "Mushaf Imam", karena boleh jadi mushaf ini yang paling awal ditulis. Meskipun bisa saja istilah Mushaf Imam digunakan untuk nama masing-masing mushaf yang dikirim ke kota-kota utama umat Islam saat itu. ${ }^{10}$

Selanjutnya Ibnul Jazari menjelaskan maksud dari shahih sanadnya adalah qiroat diriwayatkan dari orang-orang yang sangat terpercaya 'adalahnya dan tersambung hingga selesai (sampai kepada Rasulullah لله telah masyhur disisi para imam qiroat dengan tidak ada kesalahan dan penyimpangan. ${ }^{11}$

Autentisitas qiroat

Imam As Suyuthi menyimpulkan macam-macam qiroat untuk memastikan autentisitasnya:

1. Al Mutawatir adalah bacaan yang dinukil secara ijma' serta tidak mungkin mereka (para imam qiroat) membuat kesepakatan berdasarkan kedustaan, mulai dari level mereka hingga ke puncak silsilah sanad dan qiroat secara umum adalah demikian keadaannya.

2. Al Masyhur adalah bacaan yang shohih sanadnya namun tidak mencapai derajat mutawatir, sesuai dengan kaidah bahasa Arab dan Rasm 'Utsmani dan telah masyhur dihadapan para ahli membaca Alquran. Maka tidak terdapat kesalahan dan penyimpangan serta bacaan tersebut termasuk bacaan Alquran yang dibaca. Hal ini berdasarkan apa yang telah disebutkan oleh Ibnul Jazari dan dipahami dari pendapatnya Abi Syamah. Misal dari hal ini adalah perbedaan thariq (jalur riwayat) yang dinukil dari tujuh imam qiroat. Satu periwayat mengambil bacaan yang berbeda dengan periwayat yang lainnya. Contoh terkait hal ini sangat banyak terjadi pada farsyul huruf dari kitab-kitab qiroat seperti yang disebutkan sebelumnya. Diantara kitab-kitab yang terkenal terkait hal ini adalah "At Taysir" karya Ad Dani, Syair-syair Imam Asy Syatibi dan

\footnotetext{
${ }^{10}$ Fathoni, Ahmad, 2013, IImu Rasm Usmani, Jakarta: Institut IImu Al Qur'an \& Institut PTIQ, hal. 11

${ }^{11}$ As Suyuthi, op.cit., hal. 117
} 
terkumpul semuanya pada kitab "An Nasyr fil Qirooaatil 'Asyr" dan kitab "Taqribun Nasyr" yang keduanya ditulis oleh Ibnul Jazari.

3. Al Aahad adalah bacaan yang shohih sanadnya namun tidak sesuai dengan Rasm 'Utsmani atau kaidah bahasa Arab atau tidak terkenal sebagaimana bacaan yang telah masyhur dan tidak termasuk bacaan Alquran yang dibaca. Imam At Tirmidzi dalam kitab Jaminya dan Imam Hakim dalam kitab Mustadraknya mengumpulkan bacaan Aahad pada satu bab yang banyak diriwayatkan oleh keduanya dengan sanad yang shohih. Diantaranya yang diriwayatkan oleh $\mathrm{Al}$ Hakim dari jalur 'Ashim Al Juhduriy dari Abi Bakrah, bahwasanya

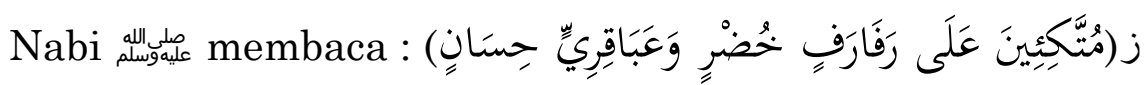

4. Asy Syaadz adalah bacaan yang tidak shohih sanadnya. Ada beberapa kitab yang memuat bacaan-bacaan syaadz ini. Diantaranya bacaan dengan shighat fi'il madhi, dan nashabnya lafadz (مَلَكَ يَوْمَ الدِّين) serta kalimat (إيََّكَ يُعْبَدُد) dengan bina maf'ul.

5. Al Maudhuu'adalah bacaan yang palsu. Seperti qirooat Al Khuzaa'iy.

6. Al Mudraj menyerupai dari beragamnya jenis hadits yaitu lafadz atau kalimat tambahan pada qirooaat untuk menafsirkan, seperti qiroat

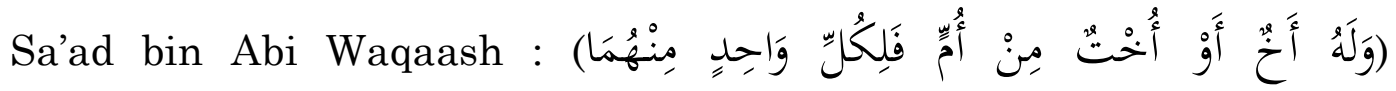
diriwayatkan Sa'id bin Manshur dan qiroat Ibnu Abbas diriwayatkan oleh Al Bukhari dan lain sebagainya.

Ibnul Jazari mengatakan pada akhir perkataannya, "Bisa jadi mereka memasukkan tafsir pada qiroat / bacaan sebagai bentuk penjelasan dan penerangan, karena mereka adalah orang-orang yang sangat mendalam ilmunya tatkala mereka menerima bacaan Alquran dari Nabi allugatale, maka mereka aman dari pencampur-adukkan bacaan, dan boleh jadi sebagian mereka menuliskan penafsiran tersebut bersamaan dengan qiroat / bacaannya. Dan adapun orang yang mengatakan bahwa sebagian sahabat membolehkan qiroat dengan maknanya, maka sungguh ia telah berdusta." 12

Sedangkan maksud dari hadits nabi aلd alus yang menyebutkan sab'atu ahruf dan disebutkan beberapa pembahasan diatas, Abul Fadl Ar Razi berpendapat bahwa arti sab'atu ahruf adalah tujuh wajah atau bentuk- maksudnya,

12 Ibid., Hal. 118-119 
keseluruhan Quran dari awal hingga akhir tidak akan keluar dari tujuh wajah perbedaan berikut ini:

1. Perbedaan pada bentuk isim (yakni antara Mufrad, Tatsniyyah atau

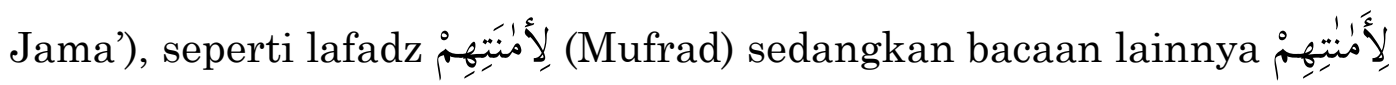
(Jama').

2. Perbedaan dalam bentuk Fi'il (yakni antara Madhi, Mudhori' atau

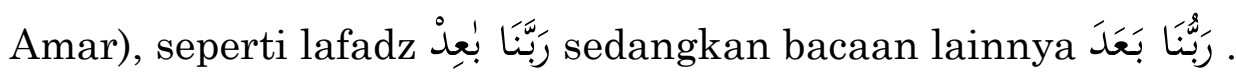

3. Perbedaan bentuk I'rab (yakni antara Rofa', Nashab, Khofadh (Jar)

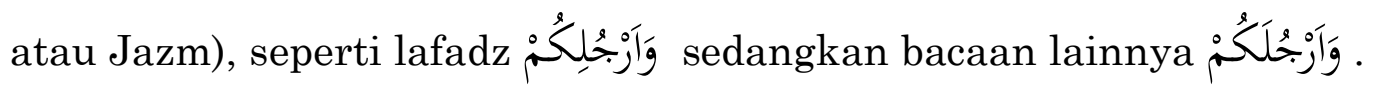

4. Perbedaan dalam bentuk Naqish dan Ziyadah, seperti وَمَا كُنَّا لِنْهَتَدِيَّ sedangkan bacaan lainnya مَا كُنَّا لِنَهْتَدِيَ

5. Perbedaan bentuk Taqdim dan Ta'khir, seperti فَيْتُلُوْنَ وَيُعْتَلُوْنَ sedangkan bacaan lainnya فَيُعْتَلْوْنَ وَيَقُُْوْنَ.

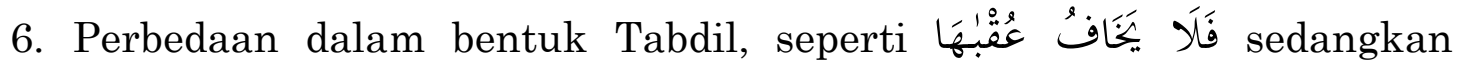

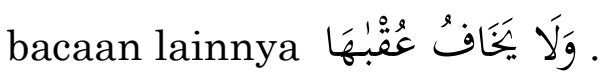

7. Perbedaan bentuk dialek (lahjah) seperti bacaan Al Imalah, At Taqlil, Al Idghom, Al Idzhar dan lain-lain. ${ }^{13}$

Adapun para Imam Qiroat yang menjadi muara riwayat bacaan terbagi menjadi tiga kelompok sebutan, yaitu Qiroah Sab'ah (Tujuh), Qiroah 'Asyrah (Sepuluh) dan Qiroah Arba'ata 'Asyar (Empat Belas). Berikut ketiga kelompok tersebut:

1. Qiroah Sab'ah (Tujuh) adalah qiroat yang diriwayatkan oleh tujuh Imam Qiroat. Yaitu Nafi', Ibnu Katsir, Abu 'Amr, Ibnu 'Amir, 'Ashim, Hamzah dan Al Kisa'i.

2. Qiroah 'Asyrah (Sepuluh) adalah qiroat yang diriwayatkan oleh tujuh Imam Qiroat dilengkapi dengan Tiga Imam Qiroat. Yaitu Ya'qub, Khalaf, dan Yaziid bin Qa'qa' (Abu Ja'far).

\footnotetext{
${ }^{13}$ Fathoni, Ahmad, 2013, IImu Rasm Usmani, Jakarta: Institut IImu Al Qur'an \& Institut PTIQ, hal. 4
} 
3. Qiroah Arba'ata 'Asyar (Empat Belas) adalah Qiroah 'Asyrah (Sepuluh) ditambah Empat Imam Qiroat. Yaitu Hasan Basri, Ibnu Muahisin, Yahya Al Yazidi dan Asy Syanabudz. ${ }^{14}$

\section{Kesimpulan}

Beragamnya bacaan Alquran beserta tulisan-tulisan yang terdapat pada mushaf-mushaf yang ada harus memenuhi kriteria 3 (tiga) syarat. Yaitu:

1. Sesuai dengan kaidah bahasa Arab

2. Sesuai dengan Rasm 'Utsmani

3. Sanadnya Shohih

Perbedaan dalam bacaan dan tulisan merupakan sebuah keniscayaan. Karena sejak awal Alquran diturunkan kepada Nabi allugale sudah memiliki beragam bacaan. Termasuk juga dalam hal penulisan. Para sahabat yang menulis disisi Nabi aلdugate memiliki beragam tulisan dan semua tulisan tersebut terakomodir pada Rasm 'Utsmani. Sebagai tambahan pengetahuan bahwa penulisan Alquran dewasa ini baik untuk riwayat Warsy, Qalun, Ad Duri dan Hafsh, memakai Rasm 'Utsmani yang diriwayatkan oleh Abu Amr Ad Dani atau Sulaiman bin Najah (Abu Daud). Untuk Indonesia, Libia, Pakistan, Irak dan lainnya menggunakan riwayat Abu Amr Ad Dani. Sedang Saudi Arabia, Mesir, Maroko dan lainnya menggunakan riwayat Sulaiman bin Najah (Abu Daud) ${ }^{15}$.

\section{E. Penutup}

Dengan demikian beberapa permasalahan bacaan Alquran dan penulisannya yang sempat membuat beragamnya tanggapan masyarakat, bahkan ada yang menanggapinya secara negatif, terjawab sudah. Yakni:

1. Dalam membaca Alquran akan lebih bijak jika disesuaikan dengan langgam yang sudah masyhur mengikuti langgam dialek Arab, meskipun secara bacaan telah memenuhi 3 (tiga) syarat, yaitu:

1) Sesuai dengan kaidah bahasa Arab

2) Sesuai dengan Rasm 'Utsmani

3) Sanadnya Shohih

2. Beragamnya bacaan dan tulisan dalam Alquran memang telah terjadi

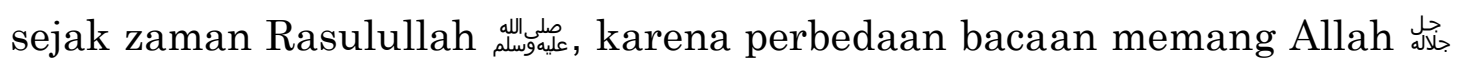

\footnotetext{
${ }^{14}$ Fathoni, Ahmad, 2016, Petunjuk Praktis Tahsin Tartil Metode Maisura, Jakarta: Yayasan Bengkel Metode Maisura, hal. 341

${ }^{15}$ Fathoni, op. cit., Hal. 24
} 
wahyukan kepada Rasulullah allugate dan penulisan bentuk huruf Alquran dilakukan disisi Rasulullah aلdugate. Adapun perbedaan tanda baca yang meliputi: titik, harokat dan tanda nomor ayat merupakan ijtihad para ulama ahli Alquran pada wilayah tertentu untuk memudahkan kaum muslimin yang awam dalam mempelajari bacaan Alquran. Ilmu yang berkaitan dengan hal ini disebut Ilmu Rasm 'Utsmani dan Ilmu Syakl wad Dhabth. Dengan demikian, mushaf yang ditemukan di wilayah Madura dan sempat diviralkan tersebut merupakan mushaf yang benar dan bukan Alquran palsu. Mushaf Alquran tersebut adalah Mushaf Alquran riwayat Warsy 'an Nafi'.

3. Dalam hal penulisan mushaf Alquran Standar Indonesia, para ulama ahli Alquran berupaya menyempurnakan penulisannya sesuai dengan Rasm 'Utsmaninya berdasarkan riwayat penulisan Abu Amr Ad Dani. Mengingat masih adanya 186 kata yang penulisannya belum sesuai dengan kaidah Ilmu Rasm 'Utsmani, maka disepakati penyempurnaannya tersebut oleh para ulama ahli Alquran Indonesia yang terhimpun pada Lajnah Pentashihan Mushaf Alquran (LPMQ). Sehingga menjadi jelas bahwa Lajnah Pentashihan Mushaf Alquran (LPMQ) tidak membuat Alquran Nusantara namun berupaya menyempurnakan penulisan sesuai dengan kaidah Ilmu Rasm 'Utsmani, karena kesesuaian bacaan dengan Rasm 'Utsmani menjadi salah satu syarat autentisitas sebuah qiroat.

Keragaman Alquran yang dimiliki umat Islam merupakan sebuah rahmat dari Allah Ta'ala untuk menjadi panduan dalam menjalani kehidupan dimuka bumi ini sebagai hamba Allah wa dan sebagai khalifah fil ardh serta sebagai khazanah keilmuan yang patut kita pelajari dan dakwahkan agar seluruh kaum muslimin terbuka pandangannya dan wawasannya sehingga dapat mempererat ukhuwah bahkan benturan-benturan ditengah upaya menguatkan ukhuwah Islamiyah dapat dikurangi.

Meskipun mushaf dan bacaan Alquran sangat beragam, namun tetap ada ketentuan yang mengikat sehingga membaca dan menulis Alquran tidak bebas tanpa aturan periwayatan. 
1. Al Qaththan, Manna Khalil. (tt). Mabahits fii 'Ulumil Qur'an. Riyadh: Ma'had Aly Lil Qadha.

2. Departemen Agama RI, 1994, Al Qur'an dan Terjemahnya, Semarang: Kumudasmoro Graffindo.

3. Fathoni, Ahmad, 2016, Petunjuk Praktis Tahsin Tartil Metode Maisura, Jakarta: Yayasan Bengkel Metode Maisura

4. As Suyuthi, Jalaluddin Abdurrahman bin Abi Bakr, 2019, Al Itqon Fi 'Ulumil Quran, Beirut: Dar Al Kotob Al Ilmiyah

5. Fathoni, Ahmad, 2013, Ilmu Rasm Usmani, Jakarta: Institut Ilmu Al Qur'an \& Institut PTIQ.

6. Fathoni, Ahmad, 2005, Kaidah Qiraat Tujuh, Jakarta: Institut Ilmu Al Qur'an \& Institut PTIQ dan Darul Ulum Press.

7. Fathoni, Ahmad, 2018, Tuntunan Praktis Qiraat Naafi' Riwayat Warsy, Jakarta: Pesantren Takhassus "IIQ Jakarta". 